\title{
Hyperprolactinemia with Galactorrhea Due to Subclinical Hypothyroidism: A Case Report and Review of Literature
}

\author{
Kashif Aziz ${ }^{1}$, Amir Shahbaz ${ }^{1}$, Muhammad Umair ${ }^{1}$, Mohaddeseh Sharifzadeh ${ }^{1}$, Issac Sachmechi ${ }^{1}$ \\ 1. Internal Medicine, Icahn School of Medicine at Mount Sinai Queen Hospital Center, New York, USA
}

Corresponding author: Kashif Aziz, kashifaziz927@gmail.com

\begin{abstract}
Hyperprolactinemia is a common finding in primary hypothyroidism, but increased prolactin in the setting of subclinical hypothyroidism ( $\mathrm{SCH}$ ) has been scarcely reported in the literature. This is a rare case of hyperprolactinemia due to $\mathrm{SCH}$ that resolved with thyroid hormone replacement therapy. The patient was not on any medications known to cause hyperprolactinemia but she was using isoniazid for her latent tuberculosis. Isoniazid therapy may explain breast pain, but there is no reported relationship between isoniazid use causing subclinical hypothyroidism and hyperprolactinemia. A literature review reveals that few cases of galactorrhea associated with subclinical hypothyroidism have been reported. Similar to the reported cases in the literature, our patient's thyroid stimulating hormone (TSH) and prolactin levels returned to normal with levothyroxine therapy.
\end{abstract}

Categories: Endocrinology/Diabetes/Metabolism, Internal Medicine

Keywords: primary hypothyroidism, subclinical hypothyroidism, levothyroxine, hyperprolactinemia, galactorrhea

\section{Introduction}

Hyperprolactinemia is common in primary hypothyroidism, but, to our knowledge, marked elevation of serum prolactin in subclinical hypothyroidism (SCH) has not been commonly reported (Sachmechi I, Reich D, Bhatti H, Kim P: Hyperprolactinemia with galactorrhea due to subclinical hypothyroidism, abstract. 2010 Abstract, The American Association of Clinical Endocrinologists,

(2010), https://www.aace.com/files/abstracts-2010.pdf ). Prolactin is a pituitary hormone that plays an important role in a number of reproductive functions. Hyperprolactinemia can result from many causes, including hypothyroidism and pituitary disorders as well as medication use. Depending on the cause and outcomes of hyperprolactinemia, selected patients need treatment [1]. Prolactin is under dual regulation by hypothalamic hormones delivered through the hypothalamic-pituitary circulation. The predominant signal is inhibitory, preventing prolactin release and is mediated by dopamine. The stimulatory signal is mediated by the hypothalamic hormone, thyrotropin-releasing hormone (TRH). In patients with hypothyroidism, an increase in prolactin is due to compensatory increase in the discharge of central hypothalamic TRH as a result of low thyroxine [1]. In the few hypothyroid patients who have elevated serum prolactin levels, the values become normal when the hypothyroidism is corrected [2]. Here we report a case of hyperprolactinemia due to $\mathrm{SCH}$, in which the prolactin level became normal after levothyroxine treatment.

\section{Case Presentation}

A 48-year-old female from Honduras presented to the clinic with chief complaints of breast tenderness and galactorrhea for the past two to three weeks. She had a past medical history of hypertension, latent tuberculosis (TB) and sciatica. Her last menstrual period was three weeks prior to her presentation. Physical examination showed non-tender, diffuse enlargement of the thyroid gland, which was unchanged over the past one year. On palpation, breast examination revealed bilateral tenderness and milky yellowish discharge. The visual field testing and rest of the general physical examination were within normal limits. She was taking hydrochlorothiazide $25 \mathrm{mg}$ and losartan $50 \mathrm{mg}$ daily for hypertension and was on isoniazid (INH) and vitamin B6 for the treatment of latent tuberculosis. She denied the use of tobacco, marijuana, alcohol, illicit drugs, or over the counter medicines. Laboratory investigations are given below (Table 1). 


\section{Cureus}

\begin{tabular}{|c|c|c|c|}
\hline Test & Units & Normal Range & Patient values \\
\hline TSH & $\mathrm{mlU} / \mathrm{ml}$ & $0.7-5$ & 5.63 \\
\hline FT4 & $\mathrm{ng} / \mathrm{dl}$ & $0.58-1.64$ & 0.75 \\
\hline Total T4 & $\mathrm{mcg} / \mathrm{dl}$ & $6.09-12.2$ & 6.96 \\
\hline Total T3 & $\mathrm{ng} / \mathrm{dl}$ & 87-178 & 91.4 \\
\hline Prolactin & $\mathrm{ng} / \mathrm{ml}$ & $3.34-26.74$ & 55.42 \\
\hline
\end{tabular}

TABLE 1: Laboratory Findings

Abbrevations: Thyroid Stimulating Hormone (TSH), Free Thyroxine (FT4), Serum Throxine (Total T4), Total Triiodothyronine (Total T3)

She had negative urine pregnancy test. Her mammogram was normal, and magnetic resonance imaging (MRI) of the brain didn’t show any pituitary mass. After looking at her thyroid function tests, prolactin level, and other respective tests, a diagnosis of subclinical hypothyroidism with hyperprolactinemia was made. She was prescribed levothyroxine $50 \mathrm{mcg}$ daily and three months later her galactorrhea and breast tenderness were relieved. Her repeat blood testing showed normal thyroid stimulating hormone (TSH) level $1.4 \mathrm{mIU} / \mathrm{ml}$ and normal serum prolactin level of $13.44 \mathrm{ng} / \mathrm{ml}$.

\section{Discussion}

Prolactin is a peptide hormone produced by lactotroph cells of the anterior pituitary gland and is primarily associated with lactation. Hyperprolactinemia results almost exclusively from diseases that cause hypersecretion of prolactin by lactotroph cells. Physiologic causes include pregnancy, nipple stimulation, and stress. Pathologic causes include lactotroph adenomas, other hypothalamic and pituitary disorders. It can be caused by medications, most commonly antipsychotics, antidepressants, and antiemetics [2]. Other causes include idiopathic hyperprolactinemia, hypothyroidism, estrogen administration, chronic renal failure, and macroprolactinemia. A germline, loss-of-function mutation in the prolactin receptor gene (PRLR) resulting in prolactin insensitivity has been identified as a cause of familial hyperprolactinemia [2]. In the United States, this condition occurs in less than $1 \%$ of the general population and in $5-14 \%$ of patients presenting with secondary amenorrhea. Approximately $75 \%$ of patients presenting with galactorrhea and amenorrhea have hyperprolactinemia. Of these patients, approximately $30 \%$ have prolactin-secreting tumors [3]. On review of literature, we found one case report of a patient with SCH associated with hyperprolactinemia that normalized with levothyroxine therapy and another case report regarding isoniazid-associated, painful, bilateral gynecomastia [4]. In our case the painful gynecomastia could be related to isoniazid use, but the galactorrhea is due to hyperprolactinemia. Since the treatment of her SCH with levothyroxine resolved her hyperprolactinemia and galactorrhea along with normalization of her TSH, it concludes that the hyperprolactinemia was due to $\mathrm{SCH}$. Review of literature regarding hyperprolactinemia and its association with SCH is given below (Table 2). 


\section{Cureus}

\begin{tabular}{|c|c|c|c|c|}
\hline $\begin{array}{l}\text { Serial } \\
\text { No. }\end{array}$ & $\begin{array}{l}\text { Author's } \\
\text { Name }\end{array}$ & Study Design & Study Summary & Treatment and Study Outcome \\
\hline 1 & $\begin{array}{l}\text { Olive KE, } \\
\text { et al. [5] }\end{array}$ & Case report & $\begin{array}{l}\text { A } 45 \text {-year-old female presented with } \\
\text { Carpal tunnel syndrome and } \\
\text { mildobesity. Her thyroxine and } \\
\text { prolactin level were } 64 \text { (nmol/L) and } \\
187 \text { (Microgram/L) }\end{array}$ & $\begin{array}{l}\text { Levothyroxine sodium } 0.1 \mathrm{mg} \text { was started. After nine weeks of } \\
\text { therapy, the patient was euthyroid and had normal } \\
\text { prolactin Levels. After one year of follow-up the patient had normal } \\
\text { prolactin levels. }\end{array}$ \\
\hline 2 & $\begin{array}{l}\text { Meier C, et } \\
\text { al. [6] }\end{array}$ & $\begin{array}{l}\text { Double } \\
\text { blinded } \\
\text { placebo } \\
\text { controlled } \\
\text { study }\end{array}$ & $\begin{array}{l}\text { They investigated the effect of } \\
\text { levothyroxine treatment on serum } \\
\text { prolactin (PRL) levels in women with } \\
\text { subclinical hypothyroidism. }\end{array}$ & $\begin{array}{l}\text { Based on the study, they demonstrated that in subclinical } \\
\text { hypothyroidism }(\mathrm{SCH}) \text {, prolactin regulation is altered and } \\
\text { levothyroxine treatment restores prolactin concentration. }\end{array}$ \\
\hline 3 & $\begin{array}{l}\text { Hekimosy } \\
\text { Z, et al. [7] }\end{array}$ & $\begin{array}{l}\text { Observational } \\
\text { study }\end{array}$ & $\begin{array}{l}\text { They did an observational study } \\
\text { to determine the prevalence of } \\
\text { hyperprolactinemia in patients with } \\
\text { newly diagnosed subclinical and } \\
\text { overt hypothyroidism and } \\
\text { investigated the change in PRL levels } \\
\text { with levothyroxine treatment. }\end{array}$ & $\begin{array}{l}\text { Prolactin level elevation was found in } 36 \% \text { of patients with overt } \\
\text { hypothyroidism and in } 22 \% \text { of patients with subclinical } \\
\text { hypothyroidism. Prolactin levels decreased to normal in all patients } \\
\text { after thyroid functions normalized with levothyroxine treatment. In } \\
\text { the hypothyroid patients (overt and subclinical) a positive } \\
\text { correlation was found between thyroid stimulating hormone (TSH) } \\
\text { and prolactin levels. }\end{array}$ \\
\hline 4 & $\begin{array}{l}\text { Iolino A, } \\
\text { et al. [8] }\end{array}$ & $\begin{array}{l}\text { Observational } \\
\text { study }\end{array}$ & $\begin{array}{l}\text { They studied a correlation between } \\
\mathrm{SCH} \text { and hyperprolactinemia and } \\
\text { sterility. }\end{array}$ & $\begin{array}{l}\text { The results of } 25 \text { women aged } 22 \text { to } 26 \text { years showed a picture of } \\
\mathrm{SCH} \text { in seven patients }(28 \%) \text {, and three patients }(12 \%) \text { had } \\
\text { galactorrhea. The increase of volume of thyroid gland was constant } \\
\text { in all women with } \mathrm{SCH} \text {. Authors point out correlation between } \\
\text { subclinical hypothyroidism-hyperprolactinemia and sterilty. }\end{array}$ \\
\hline 5 & $\begin{array}{l}\text { Empokpae } \\
\text { MA, et al. } \\
\text { [9] }\end{array}$ & $\begin{array}{l}\text { Cross- } \\
\text { sectional } \\
\text { prospective } \\
\text { study }\end{array}$ & $\begin{array}{l}\text { They studied infertile Nigerian } \\
\text { women with hyperprolactinemia with } \\
\text { subclinical hypothyroidism. }\end{array}$ & $\begin{array}{l}\text { In conclusion, they explained that } \mathrm{SCH} \text { was observed in women } \\
\text { with hyperprolactinaemia and the ratio of proportions between } \\
\text { hyperprolactinemia and hypothyroidism was } 7: 1 \text {; in simple words, in } \\
\text { every seven women with hyperprolactinemia, one had } \\
\text { hypothyroidism. }\end{array}$ \\
\hline 6 & $\begin{array}{l}\text { Atis G, et } \\
\text { al. [10] }\end{array}$ & $\begin{array}{l}\text { Cross- } \\
\text { sectional } \\
\text { study }\end{array}$ & $\begin{array}{l}\text { They did the study to investigate } \\
\text { sexual dysfunction in patients with } \\
\text { clinical hypothyroidism and SCH. }\end{array}$ & $\begin{array}{l}\text { Female sexual dysfunction was diagnosed in } 56 \% \text { of women with } \\
\text { clinical hypothyroidism, } 54.6 \% \text { in women with } \mathrm{SCH} \text {. The mean } \\
\text { prolactin levels were significantly higher in clinical hypothyroidism } \\
\text { (30.56), SCH (22.56) as compared to control healthy population } \\
\text { (13.03) (ng/ml). }\end{array}$ \\
\hline 7 & $\begin{array}{l}\text { Sharma } \\
\text { LK, et al. } \\
\text { [11] }\end{array}$ & $\begin{array}{l}\text { Cross- } \\
\text { sectional } \\
\text { prospective } \\
\text { study }\end{array}$ & $\begin{array}{l}\text { They evaluated individuals who were } \\
\text { either euthyroid or had subclinical or } \\
\text { overt hypothyroidism and their } \\
\text { correlation with TSH and prolactin. }\end{array}$ & $\begin{array}{l}\text { Significant positive correlation between TSH and prolactin was } \\
\text { noted in SCH and primary hypothyroidism. }\end{array}$ \\
\hline 8 & $\begin{array}{l}\text { Bahar } \\
\text { A, et al. } \\
{[12]}\end{array}$ & $\begin{array}{l}\text { Cross- } \\
\text { sectional } \\
\text { Study }\end{array}$ & $\begin{array}{l}\text { They did a cross-sectional study and } \\
\text { assessed the prolactin levels of } \\
\text { subclinical hypothyroid patients. }\end{array}$ & $\begin{array}{l}20.4 \% \text { (98 patients, } 91 \text { females; seven males) and } \\
\text { hyperprolactinemia with galactorrhea in } 2.6 \% \text { patients. They } \\
\text { concluded that prevalence of hyperprolactinemia in } \mathrm{SCH} \text { is notable } \\
\text { and this disorder is more common in females with subclinical } \\
\text { hypothyroidism than in men. }\end{array}$ \\
\hline
\end{tabular}

\section{TABLE 2: Review of Literature}

Abbrevations: Subclinical Hypothyroidism (SCH), Prolactin (PRL), Thyroid stimulating hormone (TSH)

\section{Conclusions}

Hyperprolactinemia with galactorrhea can occur in SCH. In such cases, treatment of SCH with levothyroxine will normalize the prolactin level. Close follow-up of serum prolactin levels should be done before, during, and after treatment in order to avoid unnecessary imaging such as MRI of the brain.

\section{Additional Information}




\section{Disclosures}

Human subjects: Consent was obtained by all participants in this study. Conflicts of interest: In compliance with the ICMJE uniform disclosure form, all authors declare the following: Payment/services info: All authors have declared that no financial support was received from any organization for the submitted work. Financial relationships: All authors have declared that they have no financial relationships at present or within the previous three years with any organizations that might have an interest in the submitted work. Other relationships: All authors have declared that there are no other relationships or activities that could appear to have influenced the submitted work.

\section{References}

1. Seri O, Chik CL, Ur E, Ezzat S: Diagnosis and management of hyperprolactinemia. CMAJ. 2003, 169:575-581.

2. Causes of hyperprolactinemia. (2017). Accessed: March 25, 2018: https://www.uptodate.com/contents/causes-of-hyperprolactinemia.

3. Hyperprolactinemia. (2018). Accessed: March 25, 2018: https://emedicine.medscape.com/article/121784overview\#a6.

4. Khanna P, Panjabi C, Maurya V, Shah A: Isoniazid associated, painful, bilateral gynaecomastia . Indian J Chest Dis Allied Sci. 2003, 45:277-9.

5. Olive KE, Hennessey JV: Marked hyperprolactinemia in subclinical hypothyroidism . Arch Intern Med. 1988, 148:2278-9. 10.1001/archinte.1988.00380100122027

6. Meier C, Christ-Crain M, Guglielmetti M, Huber P, Staub JJ, Müller B: Prolactin dysregulation in women with subclinical hypothyroidism: effect of levothyroxine replacement therapy. Thyroid. 2003, 13:1. 10.1089/105072503322511391

7. Hekimsoy Z, Kafesçiler S, Güçlü F, Ozmen B: The prevalence of hyperprolactinaemia in overt and subclinical hypothyroidism. Endocr J. 2010, 57:1011-1015. 10.1507/endocrj.K10E-215

8. Tolino A, Nicotra M, Romano L, Petrone A, Langella L: Subclinical hypothyroidism and hyperprolactinemia. Acta Eur Fertil. 1991, 22:275-7.

9. Emokpae MA, Osadolor HB, Omole Ohonsi A: Sub-clinical hypothyroidism in infertile Nigerian women with hyperprolactinaemia. Niger J Physiol Sci. 2011, 26:35-8.

10. Atis G, Dalkilinc A, Altuntas Y, Atis A, Caskurlu T, Ergenekon E: Sexual dysfunction in women with clinical hypothyroidism and subclinical hypothyroidism. J Sex Med. 2010, 7:2583-90. 10.1111/j.17436109.2010.01815.x

11. Sharma LK, Sharma N, Gadpayle AK, Dutta D: Prevalence and predictors of hyperprolactinemia in subclinical hypothyroidism. Eur J Intern Med. 2016, 35:106-110. 10.1016/j.ejim.2016.07.012

12. Bahar A, Akha O, Kashi Z, Vesgari Z: Hyperprolactinemia in association with subclinical hypothyroidism . Caspian J Intern Med. 2011, 2:229-33. 